\title{
Branched-Chain Amino Acids and Alanine as Indices of the Metabolic Control in Type 1 (Insulin-Dependent) and Type 2 (Non-Insulin-Dependent) Diabetic Patients
}

\author{
P. Vannini ${ }^{1}$, G. Marchesini ${ }^{2}$, G. Forlani ${ }^{1}$, A. Angiolini ${ }^{2}$, A. Ciavarella ${ }^{1}$, M. Zoli ${ }^{2}$ and E. Pisi ${ }^{2}$ \\ ${ }^{1}$ Cattedra e Servizio di Malattie del Ricambio, and ${ }^{2}$ Istituto di Patologia Medica 1, Università di Bologna, Bologna, Italy
}

Summary. Alterations in plasma branched-chain amino acids (valine, isoleucine and leucine) and alanine have been described in patients with insulin-dependent diabetes mellitus who have poor metabolic control. To assess the relevance of these abnormalities as indices of metabolic control, we sequentially evaluated plasma amino acids in 14 poorly controlled diabetics (seven Type 1 (insulin-dependent) and seven Type 2 (non-insulin-dependent) patients) until good control was achieved. The sum of branched-chain amino acids in both groups of uncontrolled diabetic patients was significantly increased compared with the values for the same subjects in good metabolic control. No statistically significant differences were present between ketotic and non-ketotic uncontrolled patients. The amelioration of the diabetic state with either insulin treatment or oral hypoglycaemic agents, reduced progressively branched-chain amino acids. The sum of valine, isoleucine and leucine strictly correlated with daily urinary glucose $(r=0.73)$, but less well with fasting blood glucose $(r=0.43)$, nonesterified fatty acids $(r=0.46)$ and glycosylated haemoglobin $(r=0.38)$. Alanine did not show any statistically significant differences at various stages of diabetic control. Branched-chain amino acids, but not alanine, may be used as indices of short-term diabetic control.

Key words: Branched-chain amino acids, alanine, diabetes, isoleucine, leucine, valine.

In diabetes mellitus metabolic alterations involve protein as well as carbohydrate and lipid metabolism. In uncontrolled Type 1 diabetes, plasma concentrations of the branched-chain amino acids (valine, isoleucine and leucine - BCAA) are increased [1-3], and rapidly return to normal after insulin administration
[4]. Reduced levels of alanine have also been reported, although there are conflicting data on this subject [2-3]. Branched-chain amino acids and alanine have been used as indices of metabolic control in diabetic patients treated with either intermittent or continuous subcutaneous insulin administration [5-6]. The usefulness of amino acid determinations in the assessment of the metabolic control in Type 2 diabetes is the aim of the present study.

\section{Patients and Methods}

\section{Patients}

Two groups of patients were studied. The first group comprised seven patients (five males and two females), aged 15-55 years (median 45 years), affected by Type 1 diabetes for several years (3-22 years, median 7 years). The second group consisted of seven patients (five males and two females), aged 35-65 years (median 54 years), suffering from newly diagnosed Type 2 diabetes. In the second group no therapy had been instituted before the beginning of the study. None of the 14 subjects were obese, and all had normal hepatic and renal function tests. On the first analyses all subjects were in poor metabolic control (Table 1) and in seven (five Type 1 and two Type 2 diabetic patients) ketone bodies were present in the urine. Their progress was followed either as outpatients (nine cases) or as inpatients (five cases). All of them were on a normocaloric, restricted carbohydrate diet $(26-30 \mathrm{kcal} / \mathrm{kg}$ of ideal body weight; $45 \%$ carbohydrate). Insulin treatment was continued in the seven Type 1 patients, while the Type 2 subjects received glibenclamide $(5-15 \mathrm{mg} /$ day). Analyses were repeated after 2 days of treatment and after 4-30 days (median 12 days), when a satisfactory control was achieved (fasting blood glucose $<8.8 \mathrm{mmol} / 1$; daily urinary glucose $<55 \mathrm{mmol}$ ).

Thirteen healthy subjects (ten males and three females, median age 45 years) were also studied as controls.

\section{Methods}

Venous blood samples were drawn from an antecubital vein after an overnight fast in both diabetic and control subjects. Neither insulin nor oral hypoglycaemic agents were given before sampling 
Table 1. Indices of diabetic control and plasma amino acids in diabetic and normal subjects

\begin{tabular}{|c|c|c|c|c|c|c|c|c|c|c|}
\hline & & $\begin{array}{l}\text { Blood } \\
\text { glucose } \\
(\mathrm{mmol} / 1)\end{array}$ & $\begin{array}{l}\text { Urinary } \\
\text { glucose } \\
\text { (mmol/ } \\
\text { day) }\end{array}$ & $\begin{array}{l}\text { Glycosylated } \\
\text { haemoglobin } \\
(\%)\end{array}$ & $\begin{array}{l}\text { Non-esteri- } \\
\text { fied fatty } \\
\text { acids } \\
(\mathrm{mmol} / \mathrm{l})\end{array}$ & $\begin{array}{l}\text { Alanine } \\
(\mu \mathrm{mol} / \mathrm{l})\end{array}$ & $\begin{array}{l}\text { Valine } \\
\text { (umol/1) }\end{array}$ & $\begin{array}{l}\text { Iso- } \\
\text { leucine } \\
(\mu \mathrm{mol} / 1)\end{array}$ & $\begin{array}{l}\text { Leucine } \\
(\mu \mathrm{mol} / \mathrm{l})\end{array}$ & $\begin{array}{l}\text { Branched- } \\
\text { chain amino } \\
\text { acids } \\
(\mu \mathrm{mol} / \mathrm{l})\end{array}$ \\
\hline \multicolumn{11}{|l|}{ Diabetic subjects } \\
\hline & $\begin{array}{l}\text { Type } 1 \\
\text { Type } 2\end{array}$ & $\begin{array}{l}16.2 \pm 0.8 \\
15.1 \pm 0.7\end{array}$ & $\begin{array}{l}844 \pm 161 \\
655 \pm 88\end{array}$ & $\begin{array}{l}15.7 \pm 1.0 \\
14.7 \pm 0.9\end{array}$ & $\begin{array}{l}0.89 \pm 0.08 \\
0.78 \pm 0.06\end{array}$ & $\begin{array}{l}332 \pm 49 \\
402 \pm 54\end{array}$ & $\begin{array}{l}390 \pm 49 \\
345 \pm 36\end{array}$ & $\begin{array}{l}114 \pm 16 \\
109 \pm 12\end{array}$ & $\begin{array}{l}213 \pm 28 \\
186 \pm 23\end{array}$ & $\begin{array}{l}718 \pm 91^{\mathrm{a}} \\
668 \pm 56^{\mathrm{a}}\end{array}$ \\
\hline Improved control & $\begin{array}{l}\text { Type } 1 \\
\text { Type } 2\end{array}$ & $\begin{array}{l}11.8 \pm 0.3 \\
12.5 \pm 1.1\end{array}$ & $\begin{array}{l}238 \pm 83 \\
194 \pm 50\end{array}$ & $\begin{array}{l}14.7 \pm 1.5 \\
14.4 \pm 1.4\end{array}$ & $\begin{array}{l}0.57 \pm 0.09 \\
0.58 \pm 0.04\end{array}$ & $\begin{array}{l}310 \pm 23 \\
403 \pm 62\end{array}$ & $\begin{array}{l}257 \pm 40 \\
316 \pm 24\end{array}$ & $\begin{array}{l}70 \pm 17 \\
97 \pm 7\end{array}$ & $\begin{array}{l}136 \pm 19 \\
157 \pm 18\end{array}$ & $\begin{array}{l}465 \pm 73 \\
571 \pm 45\end{array}$ \\
\hline Good control & $\begin{array}{l}\text { Type } 1 \\
\text { Type } 2\end{array}$ & $\begin{array}{l}7.4 \pm 0.7 \\
5.7 \pm 0.2\end{array}$ & $\begin{array}{l}(0-55) \\
(0-55)\end{array}$ & $\begin{array}{l}11.9 \pm 0.6 \\
11.9 \pm 0.8\end{array}$ & $\begin{array}{l}0.59 \pm 0.14 \\
0.43 \pm 0.02\end{array}$ & $\begin{array}{l}320 \pm 45 \\
336 \pm 22\end{array}$ & $\begin{array}{l}225 \pm 25 \\
271 \pm 25\end{array}$ & $\begin{array}{l}61 \pm 11 \\
74 \pm 5\end{array}$ & $\begin{array}{l}126 \pm 13 \\
132 \pm 9\end{array}$ & $\begin{array}{l}412 \pm 48^{b} \\
442 \pm 27^{c}\end{array}$ \\
\hline Healthy subjects & & $4.5 \pm 0.2$ & - & $8.1 \pm 0.1$ & $0.42 \pm 0.03$ & $342 \pm 12$ & $251 \pm 17$ & $72 \pm 9$ & $140 \pm 11$ & $453 \pm 29$ \\
\hline
\end{tabular}

Results are expressed as mean $\pm \operatorname{SEM}(n=7)$. The statistical analysis has been performed only on the values of alanine and on the sum of branched-chain amino acids.

${ }^{a}$ Significantly different from control value: $p<0.005$; ${ }^{\mathrm{b}}$ Significantly different from poor control in Type 1 diabetics: $p<0.005 ;{ }^{\mathrm{c}}$ Significantly different from poor control in Type 2 diabetics: $p<0.005$

the blood. Each sample was tested for blood glucose (Technicon autoanalyzer), non-esterified fatty acids (Clinicals, Carlo Erba, Milan, Italy), glycosylated haemoglobin (Bio-rad Laboratories, Segrate, Milan), insulin and glucagon (only in Type 2 patients) [7], and plasma free amino acids [8]. The following parameters were evaluated: the sum of valine, isoleucine and leucine (BCAA) and alanine. The amount of urinary glucose in the $24 \mathrm{~h}$ period preceding the analyses was also recorded. Statistical analysis between mean values was performed by means of Student's ' $t$ ' test for paired and unpaired data.

\section{Results}

The different indices of metabolic control and plasma amino acid values in our patients are reported in Table 1. No differences were present between Type 1 and Type 2 patients. In poorly controlled Type 1 and Type 2 subjects, BCAA levels were significantly higher when compared with control subjects and with values obtained from the same patients when a satisfactory control was achieved. No differences in plasma BCAA were observed between ketonuric $(756 \pm 94 \mu \mathrm{mol} / 1)$ and non-ketonuric uncontrolled diabetics $(630 \pm 40 \mu \mathrm{mol} / \mathrm{l}$; mean \pm SEM). In both Type 1 and Type 2 patients, the control of diabetes resulted in a progressive decline of BCAA levels, which were reduced to normal when a satisfactory control was achieved.

In contrast to BCAA levels, alanine did not show any remarkable variation in the different groups studied. In poorly controlled patients also, the presence of ketone bodies failed to alter fasting alanine levels significantly (ketonuric $323 \pm 46$; non-ketonuric 410 $\pm 55 \mu \mathrm{mol} / 1$, mean \pm SEM).

In Type 2 patients no differences in insulin were demonstrated during the different stages of the metabolic control (poor control $17 \pm 3$; improved control
$18 \pm 2$; good control $20 \pm 2 \mathrm{mU} / 1$, mean $\pm \mathrm{SEM}$ ) By contrast glucagon levels, which were high in patients at the first analyses $(46.4 \pm 5.7 \mathrm{pmol} / 1)$, progressively fell (improved control $40.7 \pm 4.3$; good control $34.5 \pm 3.1 \mathrm{pmol} / \mathrm{l}$, mean $\pm \mathrm{SEM} ; p<0.05$ compared with the corresponding values of uncontrolled diabetic patients).

In the whole group of diabetic patients, a highly significant correlation was demonstrated between fasting BCAA and daily urinary glucose levels ( $r=$ $0.73 ; p<0.001)$. Less significant correlations were found between BCAA and blood glucose or nonesterified fatty acid levels $(r=0.43$ and $r=0.46$ respectively; $p<0.01$ ), and between BCAA and glycosylated haemoglobin $(r=0.38 ; p<0.05)$. By contrast alanine did not correlate with any of the different metabolic indices considered.

\section{Discussion}

In contrast to most amino acids, BCAA are mainly oxidized in muscle and not in the liver [9-12], and their muscular uptake is under insulin control. Insulin deficiency is probably responsible for increased BCAA levels in Type 1 diabetes, while in Type 2 diabetics insulin resistance [13] or inappropriately low serum insulin levels may produce the same effect.

Glucagon levels are high in uncontrolled Type 2 patients, but a role of glucagon in metabolic alterations has been shown only with absolute insulin deficiency [14]. Therefore, in our Type 2 patients, hyperglucagonaemia can scarcely be responsible for the observed alterations in amino acid levels.

Our study demonstrated that BCAA levels are markers of short-term metabolic control in diabetes 
because of the close association with daily urinary glucose. This applies equally to both Type 1 and Type 2 diabetic patients.

In contrast, in our experience alanine does not seem to represent a marker of diabetic control, and this is in agreement with a recent study [3]. A non-significant reduction in alanine (approximately 20\%) was present only in ketotic diabetics compared with uncontrolled non-ketotic patients, possibly because of the ability of ketone bodies to decrease substrate availability for gluconeogenesis in both normal [15] and diabetic subjects [16].

From the present data we conclude that only branched-chain amino acids and not alanine can demonstrate the normalization of intermediate protein metabolism following the achievement of a satisfactory glycaemic profile. In clinical practice, however, we are not able to say if their use, in the assessment of the overall diabetic control, is of some advantage in comparison with traditional indices; moreover their use is limited by the complex procedure for their determination.

\section{References}

1. Carlsten A, Hallgren B, Jagenbuerg R, Svanborg A, Werko L (1966) Amino acids and free fatty acids in plasma in diabetes. Acta Med Scand 170:361-369

2. Felig P, Marliss E, Ohman J, Cahill GF (1970) Plasma amino acids in diabetic ketoacidosis. Diabetes 19:727-729

3. Berger M, Zimmerman TH, Bertold P, Drost H, Muller WA, Gries FA, Zimmerman H (1978) Blood amino acids levels in patients with insulin excess (functioning insulinoma) and insulin deficiency (diabetic ketosis). Metabolism 27: 793-799

4. Hanna AK, Zinman B, Nakhoda AF, Minuk HL, Stokes EF, Albisser AM, Leibel BS, Marliss EB (1980) Insulin, glucagon and amino acids during glycaemic control by the artificial pancreas in diabetic man. Metabolism 29: 321-332

5. Tamborlane WV, Sherwin RS, Genel M, Felig P (1979) Restoration of normal lipid and amino acid metabolism in diabetic patients treated with a portable insulin infusion pump. Lancet $1: 1258-1261$

6. Pickup JC, Keen H, Parsons JA, Alberti KGMM, Rowe AS (1979) Continuous subcutaneous insulin infusion: improved blood glucose and intermediary metabolite control in diabetics. Lancet 1: 1255-1257

7. Marchesini G, Forlani G, Angiolini A, Scolari MP, Zoli M, Bianchi FB, Pisi E (1979) Oral glucose in cirrhotics. Effect on plasma aminoacid patterns and the role of insulin and glucagon. Diabète Metab 5: 135-139

8. Marchesini G, Forlani G, Zoli M, Angiolini A, Scolari MP, Bianchi FB, Pisi E (1979) Insulin and glucagon levels in liver cirrhosis: relationship with plasma amino acid imbalance of chronic hepatic encephalopathy. Dig Dis Sci 24:594-601

9. Buse MG, Biggers JF, Friderici KIT (1972) Oxidation of branched-chain amino acids by isolated hearts and diaphragms of the rat. J Biol Chem 247: 8085-8096

10. Goldberg AL, Odessey R (1972) Oxidation of amino acids by diaphragms from fed and fasted rats. Am J Physiol 223: 1384-1391

11. Wahren J, Felig P, Hagenfeldt J (1976) Effect of protein ingestion on splanchnic and leg metabolism in normal man and in patients with diabetes mellitus. J Clin Invest 57:987-999

12. Felig P, Wahren J, Sherwin R, Palaiologos G (1977) Amino acid and protein metabolism in diabetes mellitus. Arch Intern Med 137: 507-513

13. Felig P, Marliss E, Cahill GF (1969) Plasma amino acid levels and insulin secretion in obesity. N Engl J Med 281:811-815

14. Sherwin RS, Fischer M, Hendler R, Felig P (1976) Hyperglucagonemia and blood glucose regulation in normal, obese and diabetic subjects. N Engl J Med 294: 455-461

15. Sherwin R, Hendler R, Felig P(1975) Effects of ketone administration on amino acid metabolism in man. $\mathrm{J}$ Clin Invest 55: $1382-1390$

16. Sherwin R, Hendler R, Felig P(1976) Effects of diabetes mellitus and insulin on the turnover and metabolic response to ketones in man. Diabetes 25:776-784

Received: 11 August 1981

and in revised form: 29 September 1981

Professor P. Vannini

Cattedra di Malattie del Ricambio

Università di Bologna

Policlinico S Orsola

9, via Massarenti

40138 Bologna, Italy 